\title{
Allium ursinum: botanical, phytochemical and pharmacological overview
}

\author{
Danuta Sobolewska • Irma Podolak • \\ Justyna Makowska-Wąs
}

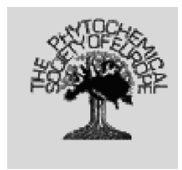

Received: 9 May 2013/Accepted: 18 December 2013/Published online: 25 December 2013

(C) The Author(s) 2013. This article is published with open access at Springerlink.com

\begin{abstract}
Ramson-Allium ursinum L. is a medicinal and dietary plant species with a long tradition of use. This mini-review summarizes the current knowledge on the phytochemistry and pharmacological properties of this valuable plant, with special emphasis on antimicrobial, cytotoxic, antioxidant, and cardioprotective effects.
\end{abstract}

Keywords Allium ursinum $\cdot$ Biological activity $\cdot$ Ramson $\cdot$ Steroidal saponins $\cdot$ Sulfur compounds

\section{Introduction}

Allium ursinum $\mathrm{L}$. has been used for centuries in traditional medicine. However, studies on its composition and pharmacological activity are fairly recent and scarce. The aim of the present review was to summarize the most important aspects related to $A$. ursinum and provide an outline of phytochemical and pharmacological properties of this relatively poorly known plant species of the Allium genus.

The species name "ursinum" is of Latin origin, being derived from "ursus" (bear), and is related to

D. Sobolewska $(\bowtie) \cdot$ I. Podolak · J. Makowska-Wąs Department of Pharmacognosy, Jagiellonian University, Medical College, 9 Medyczna Street, Kraków, Poland e-mail: dsobolew@cm-uj.krakow.pl folk tales, according to which bears after awakening from winter hibernation consume this plant to remove toxins from the body and to regain strength (Rejewski 1996). Another etymological hypothesis refers to the "Ursa major", a constellation in the northern hemisphere, perhaps because A. ursinum was, to ancient Greeks especially, one of the most northerly distributed Allium species (Böhling 2008). Contemporary systematics places this plant in the family Amaryllidaceae (previously in Alliaceae), subgenus Amerallium Traub, section Arctoprasum Kirschl. (Friesen et al. 2006; Chase et al. 2009; Govaerts 2011). Several synonyms are recognized: Allium nemorale Salisb., A. latifolium Gilib., and Ophioscorodon ursinum (L.) Wallr. Thanks to its wide-spread distribution and popularity as edible and medicinal plant, most modern European languages have common names for A. ursinum which are used interchangeably. These are: Ramson or Bear's garlic (English); Bärlauch (German); Ail des ours, Ail sauvage (French); Лук медвежий, Чеснок медвежий or Черемша (Russian); Ramslök (Swedish); Daslook (Dutch); Czosnek niedźwiedzi (Polish).

Also, the name "wild garlic" is very often used in literature with respect to A. ursinum, though it can be sometimes ambiguous, since it also refers to other species, like A. vineale or A. canadense, as well as to plants from the genus Tulbaghia (Defelice 2003; Maine Rare Plant List 2013; Lyantagaye 2011). 


\section{Description}

As far as morphological features are concerned ramson is a typical representative of the Allium genus. The plant is a bulbiferous, vernal geophyte. Its bulb is narrow, elongated, about $1.5-6 \mathrm{~cm}$ long, surrounded by the layers of clear skin with only a few fibers at the base. Sometimes daughter bulbs are formed, what is important for vegetative reproduction. Contractile roots start to develop approximately from the age of three (Eggert 1992; Ernst 1979; Szafer et al. 1988; Oborny et al. 2011; Macků and Krejča 1989; Činčura et al. 1990). When the soil is soft enough to enable the roots to dwell deeper and deeper, after 10 years they can reach down the level even $27 \mathrm{~cm}$ lower (Ellenberg 1988). Ramson grows up to the height of $50 \mathrm{~cm}$. The aerial parts of the plant consist of a triquetrous, erect, flower stem, solid in cross-section. Atop a stalk, there is a semispherical umbel-like inflorescence, which comprises of 3-30 starry, snowy-white flowers (according to Błażewicz-Woźniak: 13.4-24.0 on average). They are surrounded by $2-3$ spathal bracts until anthesis. Flower parts are in 6's sets (Eggert 1992; Ernst 1979; Berger 1960; Szafer et al. 1988; Rejewski 1996; Macků and Krejča 1989; Činčura et al. 1990; Błażewicz-Woźniak et al. 2011). Ramson's blooming usually starts in April and ends in the first half of May.

The plant develops 2-3 leaves, which are shorter than stem, smooth, flat, elliptic-lanceolate with a distinct, well-developed blade, sharpened at the apex, and gradually narrowed into petiole at the base. The width of ramson leaves is 20-64 mm (Szafer et al. 1988; Błażewicz-Woźniak and Michowska 2011). A comparative study on a collection of A. ursinum specimens from different ecotypes in Poland (Dukla, Roztocze, Bieszczady) showed that, they differed significantly in the width of leaf blades, the length of leaf stalks and flowering stems, the number of flowers in inflorescences (Błażewicz-Woźniak and Michowska 2011).

Allium ursinum regenerates mainly by seeds; vegetative regeneration is of minor importance. The seeds are black, subglobose, 2-3 $\mathrm{mm}$ wide, gathered in trichotomic capsules (Hermy et al. 1999; Sendl 1995). Mean weight per seed is $5.4 \pm 0.7 \mathrm{mg}$. They are shed in June and July, however shedding time may be delayed by weather conditions, e.g. a cold spring and summer, or north-facing aspect (Ernst 1979). Most of the seeds fall onto the ground directly beneath the capsules, but they seem to be too heavy to be moved by the wind at a ground level (Oborny et al. 2011; Ernst 1979). So, for a long-distance transport to potential growing sites the participation of animals or running water is needed (Eggert 1992). Most of the seeds remain dormant for 1 or 2 years, however, some germinate in the course of upcoming winter or spring, usually from November to March (according to Ernst it takes place from January to April) (Eggert 1992; Ernst 1979). A dense carpet of A. ursinum can produce a large number of seeds annually, even 10,000 seeds $/ \mathrm{m}^{2}$ as was recorded in Gottingen Forest (Germany) (Ernst 1979). In Litovelské Pomoraví (Czech Republic) floodplain forest, the mean seed production was estimated as 2,692 seeds per $\mathrm{m}^{2}\left(\max 5,612 \mathrm{seeds} / \mathrm{m}^{2}\right)$ (Rychnovská and Bednář 1998).

\section{Geographical distribution and habitat requirements}

Allium ursinum is a perennial herbaceous species, of wide-spread distribution both in Europe and Asia. Although, not growing at high altitudes (beyond $1.900 \mathrm{~m}$ ) and in the far North (beyond ca $64^{\circ} \mathrm{N}$ ), it can be found on natural stands from the Mediterranean region to Scandinavia (Oborny et al. 2011). It is also native to Asia Minor, the Caucasus, and Siberia, up to the Kamchatka Peninsula (Rola 2012; Madaus 1938; Oborny et al. 2011; Djurdjevic et al. 2004).

Two subspecies of $A$. ursinum are recognized: $A$. ursinum ssp. ursinum and $A$. ursinum ssp. ucrainicum. The subdivision is based on the smoothness of pedicel surface (Karpaviciene 2006). The pedicels of the ssp. ursinum are scabrid, with numerous papillae, and rough, while the ssp. ucrainicum has smooth pedicels without papillae (Rola 2012; Farkas et al. 2012). The former is distributed in western and central Europe, whereas the latter in eastern and southeastern part of the continent (Rola 2012; Oborny et al. 2011). The distribution areas of the two subspecies can overlap what results in the existence of transitional forms. In Poland, both subspecies along with the intermediate forms, occurring at the border of the distribution ranges, were recorded (Rola 2012). In West Caucasus and Germany ssp. ucrainicum is sometimes transplanted into gardens (Hanelt and Büttner 2001). Also, cultivation trials have been made in former Czechoslovakia. 
The habitat preferences are equal for both subspecies (Rola 2012). Ramson-flourishes best in light and medium, nutrient-rich, damp, but well-drained soils, in full shade and semi-shade localities (Szafer and Zarzycki 1972; Činčura et al. 1990; Oborny et al. 2011). Although the plant prefers high air humidity, it can be also found on shallow, and fairly dry, in summer months especially, calcareous soil (Eggert 1992). However, both waterlogging and drought are considered as restricting factors for ramson (Kovacs 2007). Another factor limiting its distribution is the aluminium concentration in the soil water (Andersson 1993). Under experimental conditions aluminium (at the concentration of $20 \mu \mathrm{M}$ ) severely restricted ramson root elongation. Also, the growth of new roots was poor. Ramson often forms dense populations covering large areas in horn-beam-oak and beech forests, it can even become monodominant over big areas in the herb layer in the woods (Szafer and Zarzycki 1972; Činčura et al. 1990; Oborny et al. 2011; Morschhauser et al. 2009). A. ursinum is considered as one of the species, the patchy distribution of which is a characteristic feature of the herb layer in the Hordelymo-Fagetum forest community. Under the dense carpets of these species, competition for space and light is likely to occur (Leuschner and Lendzion 2009). Furthermore, A. ursinum is a strong inter-specific competitor, which affects the growth of other herbaceous plants via soil, where phenolic phytotoxins (produced by ramson) are accumulated. It competes with other plant species also through volatile compounds (Djurdjevic et al. 2004). Experimental data from the seeds germination and seedlings growth tests have shown that aqueous extract and volatile compounds of ramson bulbs inhibited other plants (lettuce, amaranth and wheat) growth stronger than extract from the leaves (Djurdjevic et al. 2004).

The period of active growth of $A$. ursinum lasts 3.5-4 months starting in early spring, between late February and early March, before the full development of tree leaves (e.g. in the northern Vienna Woodsapproximately 60 days before) (Jandl et al. 1997). This provides enough of light in the first stage of the plant growth and helps to avoid competition for light with the canopy (Shmanova and Krichfalushii 1995; Oborny et al. 2011). In late spring however, the canopy cover protects the plant from direct sunlight and helps to keep the appropriate humidity of the topsoil air. Rapid development of ramson stands is associated with high assimilation rate, and accumulation of nutrients stored in the bulbs (Jandl et al. 1997). The above-ground parts abruptly wither as summer arrives. The mortality rate of $A$. ursinum during the first 2 years of life is estimated at around $21 \%$ (Bierzychudek 1982). In the following year it increases as the plant develops contractile roots which are more subjected to attack by insects and nematodes (Ernst 1979). It is estimated that only about $1-10 \%$ of ramson seedlings reach the reproductive age (Bierzychudek 1982). The estimated average life span and age of the first sexual reproduction for A. ursinum are 8-10 and 4-5 years respectively.

\section{Chemical constituents}

Allium ursinum has a distinct garlic-like scent associated with the presence of sulfur-containing compounds which are the most characteristic constituents in Allium plants.

\section{Sulfur compounds}

These are undoubtedly the most important ramson's constituents, both in terms of chemotaxonomic value and pharmacological activity. Their qualitative and quantitative profile is subject to great variation, the predominant reason for which is their lability. Of the various sulfur compounds present in this, as well as other Allium species, glutamyl peptides and sulfoxides are considered as primary. Usually, these plants contain a high concentration of $S$-alk(en)yl-L-cysteine-sulfoxides-odorless, non-volatile sulfur secondary metabolites, which, following subsequent hydrolysis, give rise to many volatile compounds, including thiosulphinates and (poly)sulfides responsible for specific Allium flavor and odor (Boscher et al. 1995; Yoo and Pike 1998).

Ramson belongs to a methiin/alliin-type Allium species, which means it contains mainly a mixture of $(+)$-S-methyl-L-cysteine-sulfoxide (methiin) and (+)$S$-allyl-L-cysteine-sulfoxide $=(+)-S$-2-propenyl-Lcysteine-sulfoxide (alliin) (Schmitt et al. 2002; Kubec et al. 2000). However, isoalliin-(+)-S-(1-propenyl)L-cysteine-sulfoxide and propiin-(+)-S-propyl-Lcysteine-sulfoxide are present as well (Fig. 1) (Schmitt et al. 2002). Also, ethiin ( $S$-ethyl-cysteine-sulfoxide) was reported in the sample of fresh leaves 
Fig. 1 Allium ursinum cysteine-sulfoxides<smiles>CS(=O)CC(N)C(=O)O</smiles>

Methiin<smiles>C=CCS(=O)CC(N)C(=O)O</smiles>

Alliin<smiles>C/C=C/S(=O)CC(N)C(=O)O</smiles>

Isoalliin<smiles>CCCS(=O)CC(N)C(=O)O</smiles>
Propiin<smiles>CCS(=O)CC(N)C(=O)O</smiles>

Ethiin

collected in April in Czech Republic (Kubec et al. 2000).

The quantitative profile of cysteine-sulfoxides depends on the plant organ and time of harvest. Their total content in the leaves collected in April, expressed as $\mathrm{mg} / 100 \mathrm{~g}$ of fresh weight, was 101.9 (in this: methiin-60.0, ethiin-0.4, propiin-1.2, alliin40.3, isoalliin-traces) (Kubec et al. 2000). The content of total cysteine sulfoxides in the bulbs harvested in late summer, calculated as alliin, was $0.26 \%$ (amount was related to the fresh weight) (Keusgen et al. 2003). In water extracts from cloves and leaves containing hydrolytic enzyme inhibitor, the alliin content ranges were: for cloves $-0.65-1.10$ and for leaves $0.20-0.72$; while methiin: $0.60-1.40$ and 0.30-0.95, respectively (Sendl 1995). The relative proportions of cysteine sulfoxides in ramson are presented in Table 1 (Fritsch and Keusgen 2006).

The analysis of the changes in the total cysteine sulfoxides content in different parts of A. ursinum collected in Germany throughout the vegetation period (focused on the months from March to June)

showed that the highest amounts in leaves, storage leaves and bulbs $(0.42,0.26,0.38 \%$ respectively) were reached in March and April, that is before flowering time (Schmitt et al. 2002, 2005). Samples of fruits and leaf stalks collected in June contained 0.25 and $0.15 \%$ of cysteine sulfoxides (fw) respectively. Furthermore, the relative quantitative profile of the investigated sulfoxides (alliin, methiin, isoalliin and propiin) differed during the vegetation period. In March the bulb contained almost the same amounts of alliin and methiin. In the following weeks alliin became the main component $(73 \pm 18 \%)$, while methiin content decreased to $15 \pm 9 \%$ in mid-May (Schmitt et al. 2005). Then, the rise of methiin levels was observed. The relative content of propiin was always below $5 \%$, while of isoalliin $\sim 10 \%$.

As was mentioned above, cysteine sulfoxides are subject to hydrolytic cleavage leading to a formation of a number of characteristic volatile secondary products. This is performed by specific enzymes, named C,S-lyases, which catalyse the cleavage of the $\mathrm{C} \beta-\mathrm{S} \gamma$ bond of the sulfoxides. In the intact cell, cysteine sulfoxides are localized in the cytoplasm, while the hydrolytic enzyme is found in vacuoles. Cellular compartmentalization damage results in its release, and subsequent hydrolysis of sulfoxides (Boscher et al. 1995; Sendl 1995). This reaction occurs upon tissue damage, e.g. when the organ is crushed, minced, or otherwise processed, or in case of the pathogens attack (Ankri and Mirelman 1999).

$\mathrm{C}, \mathrm{S}$-lyase isolated from ramson has a molecular mass of $150,000 \mathrm{Da}$ and consists of three subunits (Landshuter et al. 1994). The optimal $\mathrm{pH}$ and temperature for its activity were established at 6.0 and $35{ }^{\circ} \mathrm{C}$, respectively. After $30 \mathrm{~min}$. of incubation at $\mathrm{pH} 3.0$ ramson's C,S-lyase lost its activity by $90 \%$. Nevertheless, its enzymatic properties are maintained at low temperatures, what was observed even after ramson cloves were freezed at $-20{ }^{\circ} \mathrm{C}$. It seems that such feature of the C,S-lyase system provides all year long protection for the underground parts of the plant after disruption of the parenchyma. In contrast to similar
Table 1 The relative proportions of cysteine sulfoxides in leaves and bulbs of ramson (adapted from Fritsch and Keusgen 2006)

\begin{tabular}{llllll}
\hline $\begin{array}{l}\text { Total content } \\
\text { (average) }(\%)\end{array}$ & $\begin{array}{l}\text { Relative } \\
\text { methiin }(\%)\end{array}$ & $\begin{array}{l}\text { Relative } \\
\text { alliin }(\%)\end{array}$ & $\begin{array}{l}\text { Relative } \\
\text { isoalliin }(\%)\end{array}$ & $\begin{array}{l}\text { Relative } \\
\text { propiin }(\%)\end{array}$ & $\begin{array}{l}\text { Origin of } \\
\text { material }\end{array}$ \\
\hline 0.245 & 39 & 24 & 37 & 0 & $\begin{array}{c}\text { Urft in } \\
\text { der Eifel }\end{array}$ \\
0.164 & 35 & 28 & 37 & 0 & \\
\hline
\end{tabular}


enzymes isolated from A. sativum, A. сера or $A$. porrum, ramson's C,S-lyase is not a glycoprotein. This was revealed as no interaction with Concanavalin-ASepharose, and no staining by periodic acid Schiffreagent, were observed. The enzyme was however sensitive to low hydroxylamine concentrations. The ramson's C,S-lyase catalyses $S$-alk(en)yl-cysteinesulfoxides hydrolysis, with alliin as the most preferred substrate (Landshuter et al. 1994). Its comparison with common garlic's alliinase showed that even though it is less specific to alliin, it still shows higher relative activity towards other cysteine sulfoxides, especially methiin and isoalliin (Schmitt et al. 2005). The primary products formed as a result of C,S-lyases action are thiosulfinates, pyruvic acid, and ammonia.

Thiosulfinates are regarded as primarily responsible for odor and flavor of freshly prepared ramson macerates, and of the products obtained by both the extraction and an unorthodox kind of distillation conducted at room temperature (Block et al. 1992). The results showed that room temperature steam distillation provides half the amount of thiosulfinates obtained by direct extraction (Block et al. 1992).

The major thiosulfinates found in ramson extracts are allicin (diallyl thiosulfinate $=$ di-2-propenyl thiosulfinate), and methyl-allyl- or dimethyl thiosulfinates (Fig. 2) (Sendl and Wagner 1991). According to Sendl they constitute 75-90\% of all the compounds formed immediately after hydrolysis of cysteine sulfoxides (Sendl 1995). Data from quantitative HPLC determination of thiosulfinates in chloroform extracts from leaves and bulbs, refered to dry weight, is presented in Table 2 (Sendl and Wagner 1991). In a ramson freezedried powder total thiosulfinates concentrations expressed as molar percentage of total was 21 (based on the weight of powder) (Block et al. 1992).

Thiosulfinates are unstable, reactive compounds, that easily decompose to (poly)sulfides, dithiins, ajoenes, and other volatile and non volatile compounds. This takes place on storage, during processing, e.g. in the presence of organic solvents, and also when heat-treated. Allicin is very unstable even at room temperature. Studies by Bagiu et al. (2010) showed that after $20 \mathrm{~h}$ at $20{ }^{\circ} \mathrm{C}$ it decomposed completely resulting in di-2-propenyl disulfide, di-2propenyl trisulfide, di-2-propenyl sulfide, and sulfur dioxide.

Vinyldithiins are cyclic compounds which are another group of degradation products of allicin. They
Fig. 2 Major thiosulfinates found in ramson extracts

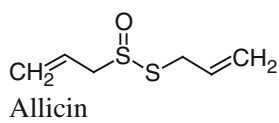

$\mathrm{CH}_{3}^{-\mathrm{OII}}-\mathrm{S} \sim \mathrm{CH}_{2}$

Methyl-allyl thiosulfinate

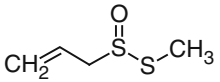

Allyl-methyl thiosulfinate

$\mathrm{CH}_{3}^{-} \stackrel{\mathrm{O}}{\mathrm{O}}{ }_{-} \mathrm{S}^{-}-\mathrm{CH}_{3}$

Dimethyl thiosulfinate

Table 2 Data from quantitative HPLC determination of thiosulfinates in chloroform extracts from leaves and bulbs of Allium ursinum (adapted from Sendl and Wagner 1991)

\begin{tabular}{llll}
\hline Plant material & Allicin (\%) & MATS (\%) & DMTS (\%) \\
\hline A. ursinum bulbs & 0.53 & 0.70 & 0.27 \\
A. ursinum leaves & 0.13 & 0.26 & 0.13 \\
\hline
\end{tabular}

MATS allyl-methyl and/or methyl-allyl thiosulfinate, DMTS dimethyl thiosulfinate

are formed as reaction products in solvents less polar than 2-propanol, e.g. hexane (Sendl 1995). It was also observed that pure allicin due to its thermolabile nature degraded to vinyldithiins during GLC analysis. In the hexane extract from the bulbs of A. ursinum Wagner and Sendl (1990) identified 2-vinyl-4H-1,3dithiin and 3-vinyl-4H-1,2-dithiin (Fig. 3). Vinyldithiins (3,4-dihydro-3-vinyl-1,2-dithiin and 2-vinyl$4 \mathrm{H}-1,3$-dithiin) were identified also in the essential oil isolated from the leaves and flowers of ramson samples collected in Bulgaria (Ivanova et al. 2009).

Another group of thiosulfinates degradation products, namely ajoene, methyl- and dimethyl ajoenes, were identified in acetone-chloroform extracts from ramson bulbs (Fig. 3). Comparative analysis of $A$. sativum and $A$. ursinum extracts showed that ajoene dominated in garlic, while its methyl- and dimethyl homologues were the main components in ramson extract (Wagner and Sendl 1990). It should be mentioned that ajoenes and vinyldithiins were found as well in oil-macerated garlic (Benkeblia and Lanzotti 2007).

Apart from the above-mentioned sulfur-containing sulfoxides degradation products, various sulfur 


$$
\begin{aligned}
& \mathrm{R}, \mathrm{R}^{\prime}=\text { allyl; Ajoene } \\
& \mathrm{R}, \mathrm{R}^{\prime}=\text { allyl, methyl; Methyl ajoene } \\
& \mathrm{R}, \mathrm{R}^{\prime}=\text { methyl; Dimethyl ajoene }
\end{aligned}
$$

Fig. 3 Ajoenes and dithiins present in A. ursinum extracts

compounds have also been detected as constituents of ramson's essential oil. This was obtained $(0.007 \%)$ for the first time already in 1887 by Semmler, who identified alkyl sulfides, alkyl polysulfides, and trace amounts of mercaptan (Sendl 1995).

The amount of oil varies depending on soil condition, geographical location, and part used. For example, isolation of essential oil from fresh and airdried leaves and flowers of ramson collected in Bosnia yielded $0.011 \%(\mathrm{w} / \mathrm{w})$ and $0.024 \%(\mathrm{w} / \mathrm{w})$ respectively (Copra-Janicijevic et al. 2008). The results of qualitative analyses of essential oils from ramson collected from different sites in Europe showed significant differences in their composition (Table 3). Furthermore, different time of harvest and analytical method applied influenced the profile of investigated oils.

From among over 20 components identified in the volatile oil of A. ursinum collected in Serbia, the most abundant fraction was disulfides (54.7\%), followed by trisulfides (37.0\%), tetrasulfides (4.7\%), and the nonsulfur components (1.0\%) (Godevac et al. 2008). The composition of essential oils of three ecotypes of $A$. ursinum collected in Poland also differed significantly in the dominant components (Błażewicz-Woźniak and Michowska 2011). The Roztocze ecotype contained methyl-2-propenyl disulfide ( $16.05 \%$ on average), 6,10,14-trimethyl-2-pentadecanone $(13.55 \%)$, nonanal $(11.93 \%)$, and dimethyl trisulfide $(12.07 \%)$ as main components. The Dukla ecotype oil was composed mainly of phytol (17.03\%) and $n$-hexadecanoic

\begin{tabular}{|c|c|c|c|c|c|c|}
\hline \multirow[t]{2}{*}{ Compounds } & \multicolumn{6}{|c|}{ Origin of plant material } \\
\hline & $* 1$ & $* 2$ & $* 3$ & $* 4$ & $* 5$ & $* 6$ \\
\hline Sulfide, methyl 2-propenyl & & & + & & & \\
\hline Sulfide, di-2-propenyl & & & + & & & \\
\hline Propylene sulfide & + & & & & & \\
\hline Disulfide, methyl 2-propenyl & + & + & + & + & + & + \\
\hline Disulfide, methyl propyl & & + & + & + & + & + \\
\hline $\begin{array}{l}\text { Disulfide, methyl 1-propenyl, } \\
(E) \text { - }\end{array}$ & & + & + & + & + & + \\
\hline $\begin{array}{l}\text { Disulfide, methyl 1-propenyl, } \\
\text { (Z)- }\end{array}$ & & & + & & & \\
\hline Disulfide, dimethyl & + & & + & + & + & + \\
\hline Disulfide, dipropyl & & & + & & & \\
\hline Hex-3-en-1-ol, $(E)$ - & & + & + & & & \\
\hline Disulfide, di-2-propenyl & + & + & + & + & + & + \\
\hline Disulfide, 2-propenyl propyl & + & + & + & & & \\
\hline Allyl (E)-1-propenyl disulfide & & + & + & & & \\
\hline Disulfide, 1-propenyl propyl, cis & & & + & & & \\
\hline $\begin{array}{l}\text { Disulfide, 1-propenyl propyl, } \\
\text { trans }\end{array}$ & & & + & & & \\
\hline Nonanal & & + & & + & + & \\
\hline Trisulfide, methyl 2-propenyl & + & + & & + & + & + \\
\hline Trisulfide, methyl propyl & & + & + & & & \\
\hline Trisulfide, dimethyl & + & + & + & + & + & + \\
\hline $\begin{array}{l}\text { Trisulfide, methyl 1-propenyl, } \\
\text { (Z)- }\end{array}$ & & + & & & & \\
\hline $\begin{array}{l}\text { Trisulfide, methyl 1-propenyl, } \\
(E) \text { - }\end{array}$ & & + & & & & \\
\hline Tetrasulfide, dimethyl & + & + & & + & + & + \\
\hline Trisulfide, dipropyl & + & & + & & & \\
\hline Trisulfide, di-2-propenyl & + & + & & + & + & + \\
\hline Trisulfide, propyl 2-propenyl & & + & & & & \\
\hline $\begin{array}{l}\text { Trisulfide, 1-propenyl } \\
\text { 2-propenyl, }(Z) \text { - }\end{array}$ & & + & & & & \\
\hline $\begin{array}{l}\text { Trisulfide, 1-propenyl } \\
\text { 2-propenyl, }(E) \text { - }\end{array}$ & & + & & & & \\
\hline Tetrasulfide, methyl 2-propenyl & & + & & + & + & + \\
\hline Tetrasulfide,di-2-propenyl & + & + & & + & + & + \\
\hline $\begin{array}{l}\text { 1-Propene, 3,3'-thiobis- } \\
\text { (CAS\#592-88-1) }\end{array}$ & & & & & + & + \\
\hline Propylthiol & & & + & & & \\
\hline Dimethylthiophene & + & & + & & & \\
\hline Pentanal, 2-methyl & & & + & & & \\
\hline 2-Hexenal & + & & + & & & \\
\hline Cumene & & & & & + & + \\
\hline
\end{tabular}
acid $(16.57 \%)$, while in the oil of the Bieszczady ecotype phytol acetate $(16.40 \%)$ and $(E)$ - $\beta$-ionone $(13.33 \%)$ dominated (Błażewicz-Woźniak and
Table 3 Composition of essential oils isolated from Allium ursinum leaves collected at different sites in Europe (Ivanova et al. 2009; Godevac et al. 2008; Schmitt et al. 2005; Błażewicz-Woźniak and Michowska 2011) 
Table 3 continued

\begin{tabular}{|c|c|c|c|c|c|}
\hline \multirow[t]{2}{*}{ Compounds } & \multicolumn{5}{|c|}{ Origin of plant material } \\
\hline & & $* 2 * 3$ & $* 4$ & $* 5$ & $* 6$ \\
\hline Benzene, 1-ethyl-4-methyl & & & & + & \\
\hline 1,2,3-Trimethylbenzene & & & tr. & + & + \\
\hline 5-Hepten-2-one, 6-methyl & & & & + & \\
\hline$n$-Octanal & & & tr. & + & + \\
\hline Cyclohexanone, 2,2,6-trimethyl & & & + & + & \\
\hline 1-Propene, 1-(methylthio)-, (Z)- & & & + & + & + \\
\hline 1-Propene, 1-(methylthio)-, $(E)-$ & & & + & + & tr. \\
\hline Decenal & & & + & + & tr. \\
\hline $\begin{array}{l}\text { 1-Cyclohexene-1-acetaldehyde, } \\
\text { 2,2,6-trimethyl }\end{array}$ & & & tr. & + & \\
\hline $\begin{array}{l}\text { 2H-1-benzopyran } 3,4,4 \mathrm{a}, 5,6,8 \mathrm{a}- \\
\text { hexahydro- } 2,5,5,8 \mathrm{a}- \\
\text { tetramethyl, }(2 \alpha, 4 \mathrm{a} \alpha \alpha, 8 \mathrm{a} \alpha) \text { - }\end{array}$ & & & + & + & + \\
\hline $\begin{array}{l}\text { 2,6,10,10-Tetramethyl-1-oxa- } \\
\text { spiro[4,5]dec-6-ene }\end{array}$ & & & + & + & \\
\hline 2-Undecanone, 6,10-dimethyl & & & tr. & + & \\
\hline (E)- $\beta$-caryophyllene & & & + & + & \\
\hline Geranyl acetone & & & + & + & + \\
\hline Alloaromadendrene & & & + & + & \\
\hline (E)- $\beta$-ionone & & & + & + & + \\
\hline 2-Tridecanone & & & + & + & + \\
\hline $\begin{array}{l}\text { 1,6,10-Dodecatrien-3-ol, 3,7,11- } \\
\text { trimethyl }\end{array}$ & & & & + & \\
\hline 2-Hexadecanol & & & & + & \\
\hline Spathulenol & & & + & + & + \\
\hline Caryophyllene oxide & & & + & + & + \\
\hline 1-Tetradecanal & + & & + & + & + \\
\hline Pentadecanal & & & + & + & + \\
\hline $\begin{array}{l}\text { 2-Pentadecanone, } 6,10,14- \\
\text { trimethyl }\end{array}$ & & & + & + & + \\
\hline $\begin{array}{l}\text { 5,9,13-Pentadecatrien-2-one, } \\
\text { 6,10,14-trimethyl, }(E, E) \text { - }\end{array}$ & & & + & + & + \\
\hline Phytol & + & & + & + & + \\
\hline$n$-Hexadecanoic acid & & & + & + & + \\
\hline Phytol acetate & & & + & + & + \\
\hline 2-Vinyl-1,3-dithiane & + & & & & \\
\hline 3,4-Dihydro-3-vinyl-1,2-dithiin & + & & & & \\
\hline 2-Vinyl-4H-1,3-dithiin & + & & & & \\
\hline 2-Hexenol & + & & & & \\
\hline 1-Hexadecanal & + & & & & \\
\hline 1-Octadecenol & + & & & & \\
\hline 1-Octadecen & + & & & & \\
\hline Heneicosane & + & & & & \\
\hline Tricosane & + & & & & \\
\hline Tetracosane & + & & & & \\
\hline
\end{tabular}

Table 3 continued

\begin{tabular}{|c|c|c|c|c|c|c|}
\hline \multirow[t]{2}{*}{ Compounds } & \multicolumn{6}{|c|}{ Origin of plant material } \\
\hline & $* 1$ & $* 2$ & $* 3$ & $* 4$ & $* 5$ & $* 6$ \\
\hline Pentacosane & + & & & & & \\
\hline Hexacosane & + & & & & & \\
\hline Heptacosane & + & & & & & \\
\hline Nonacosane & + & & & & & \\
\hline Phytol isomer & + & & & & & \\
\hline
\end{tabular}

tr. Traces

*1 Leaves harvested in the vicinity of Ihtiman, Bulgaria; the oil obtained by hydrodistillation method; GC/MS analysis (Ivanova et al. 2009)

*2 Leaves collected in the vicinity of Belgrade, Serbia; hydrodistillation; GC/MS analysis (Godevac et al. 2008)

*3 The samples collected in the area of Quedlinburg, Germany; the investigation by SPME-GC (Schmitt et al. 2005)

*4 The plant material harvested in Dukla, Poland

*5 Roztocze region, Poland

*6 Bieszczady, Poland; isolation of the oil by steam distillation; GC/MS analysis (Błażewicz-Woźniak and Michowska 2011)

Michowska 2011). The results of SPME-GC analysis of ramson oil, from the leaves collected in the area of Quedlinburg (Germany) showed that diallyl disulfide was the major component, amounting to $\sim 50 \%$ (Schmitt et al. 2005). Allyl-methyl disulfide, allylmethyl sulfide, diallyl sulfide, and $(E)$-allyl-1-propenyl disulfide were abundant, as well. However, according to the authors, the SPME method did not supply information on some other volatile substances, such as 2-hexenal or hex-3-en-1-ol, which were detected by an SDE-GC method. GC/MS analysis of samples from fresh flowers collected in the vicinity of Ihtiman (Bulgaria), showed that the main components of the volatile fraction were $(E)$-methyl-2-propenyl disulfide, methyl-2-propenyl trisulfide, dimethyl trisulfide, 3,4dihydro-3-vinyl-1,2-dithiin and 2-vinyl-4H-1,3-dithiin (Ivanova et al. 2009). Schmitt et al. (2005) detected the decrease of the relative yield of oil (sum of volatile substances) during the vegetation period, and observed that this was in agreement with the decreasing amounts of cysteine sulfoxides. An especially significant decrease in allyl methyl disulfide and dimethyl disulfide levels was seen, while the relative content of $(E)$ allyl-1-propenyl disulfide increased.

Apart from studies on the composition of steamdistilled essential oil from ramson, a very interesting 
aspect is investigation of the atmospheric emission rate of organic sulfur compounds. Such studies were conducted in a Viennese suburban forested park in which A. ursinum was grown as ground cover (Puxbaum and König 1997). Sulfur emission rates ( $\mu \mathrm{g} \mathrm{S}$ ) per gram of dry weight and per unit of ground area were $1 \mu \mathrm{g} / \mathrm{g} \times \mathrm{h}$ and $60 \mu \mathrm{g} / \mathrm{m}^{2} \times \mathrm{h}$, respectively. The authors claimed this was the highest rate ever reported for such substances emitted from a terrestrial plant.

\section{Phenolics}

Apart from sulfur-containing substances A. ursinum has been also reported to be a good source of phenolic compounds. It should be mentioned, however that the extraction method may substantially alter the level of active compounds isolated. Total polyphenol content, expressed as gallic acid equivalents (GAE), in the leaf extract obtained by a 12-day maceration with $70 \%$ ethanol at room temperature $\left(20^{\circ} \mathrm{C}\right)$ was higher in comparison with the one prepared by the ultrasoundassisted extraction: $27.9 \mathrm{~g}$ GAE/100 g dry basis versus $\sim 10 \mathrm{~g} \mathrm{GAE} / 100 \mathrm{~g}$ (Gîtin et al. 2012). Total free phenolics content in the leaves was determined as $3.24 \mathrm{mg} / \mathrm{g}$, while in the bulbs $2.30 \mathrm{mg} / \mathrm{g}$. The amount of bound forms was about the same in the leaves and in the bulbs (1.10 and 1.00 respectively) (Djurdjevic et al. 2004). Gross differences were also noted in studies on gallic acid levels. Its qualitative and quantitative analysis in hydroalcoholic extracts from A. ursinum leaves showed that: $96 \%$ methanol extract had a gallic acid content $0.0576 \mathrm{mg} / \mathrm{ml}, 80 \%$ methanol extract $-0.0165 \mathrm{mg} / \mathrm{ml}$; while $96 \%$ ethanol extract $-0.0076 \mathrm{mg} / \mathrm{ml}$ (Condrat et al. 2010).

The studies on the content of phenolic acids in fresh leaves and bulbs of ramson collected in an experimental forest situated in West Serbia exhibited some differences between free and bound compounds in these plant parts (Djurdjevic et al. 2004). The amounts of free phenolic acids in leaves and bulbs were 119.75 and $180.91 \mu \mathrm{g} / \mathrm{g}$, respectively, while of bound forms -135.30 and $248.97 \mu \mathrm{g} / \mathrm{g}$, respectively. The leaves contained free forms of ferulic and vanillic acids, and bound forms of $p$-coumaric, ferulic and vanillic acids. In the bulbs free ferulic, $p$-hydroxybenzoic and vanillic acids, and bound forms of $p$ coumaric and ferulic acids were detected.

The flavonoid content (expressed as mg quercetin equivalent-QE) determined in fresh leaves collected in March, from the Bacau city forests (Romania), using ultrasound-assisted extraction was $\sim 7.3 \mathrm{mg} \mathrm{QE} / \mathrm{kg}$ fresh plant; while using conventional maceration$2.7 \mathrm{mg} \mathrm{QE} / \mathrm{kg}$ (Gîtin et al. 2012). Also, the total content of flavonoids in the different parts of $A$. ursinum collected in June in the forest area near Wrocław (Poland) differed significantly: seeds$73.14 \mathrm{mg} / 100 \mathrm{~g}$ of dry mass, stalks-206.07 mg/ $100 \mathrm{~g}$, green leaves-1,856.31 mg/100 g, yellow leaves 2,362.96 mg/100 g (Oszmiański et al. 2013).

As far as qualitative profile is concerned, ramson is abundant predominantly in kaempferol derivatives. The ethanol extract from the leaves collected near Laceno Lake (Italy) yielded: $3-O$ - $\beta$-neohesperidoside7-O-[2-O-(trans-p-coumaroyl)]- $\beta$-D-glucopyranoside (1), 3-O- $\beta$-neohesperidoside-7- $O$-[2- $O$-(trans- $p$-feruloyl)]- $\beta$-D-glucopyranoside (2), 3- $O$ - $\beta$-neohesperidoside-7- $O$-[2-O-(trans- $p$-coumaroyl)- $\beta$-D-glucopyranosyl]- $\beta$-D-glucopyranoside (3), 3-O- $\beta$-neohesperido side-7- $O$ - $\beta$-D-glucopyranoside (4), 3-O- $\beta$-neohesperidoside (5) (Carotenuto et al. 1996). From the $n$-butanol fraction of the dry leaves of ramson collected in Denmark seven flavonoid glycosides were isolated. Three of them have been previously reported by Carotenuto et al. (compounds 1, 4, 5). The remaining were also identified as kaempferol derivatives: $3-O-\beta$ D-glucopyranoside, 3-O- $\beta$-D-glucopyranosyl-7- $O-\beta$ D-glucopyranoside, 3- $O$ - $\alpha$-L-rhamnopyranosyl-( $1 \rightarrow 2$ )[3-acetyl]- $\beta$-D-glucopyranoside and 3-O- $\alpha$-L-rhamnopyranosyl-( $1 \rightarrow 2)$-[6-acetyl]- $\beta$-D-glucopyranoside (Wu et al. 2009). Compounds 4, 5, kaempferol 3-O- $\beta$ D-glucopyranoside and kaempferol 3-O- $\beta$-D-glucopyranosyl-7- $O$ - $\beta$-D-glucopyranoside were isolated from the $n$-butanol extract from fresh flowers (Ivanova et al. 2009). The analysis of flavonoid content in acidified methanol extracts from green and yellow leaves, stalks and seeds collected in June in the forest area near Wrocław (Poland) led to the isolation of 21 compounds, all kaempferol derivatives (Oszmiański et al. 2013).

\section{Steroidal glycosides}

Similarly to organosulfur compounds, steroidal saponins are also commonly found in the Allium genus. The following were reported in the bulbs of A. ursinum: diosgenin 3-O- $\alpha$-L-rhamnopyranosyl-( $1 \rightarrow 4)$ - $\alpha$-L-rhamno pyranosyl-(1 $\rightarrow 4)$-[ $\alpha$-L-rhamnopyranosyl- $(1 \rightarrow 2)$ ]$\beta$-D-glucopyranoside and (25R)-spirost-5,25(27)-dien- 
Fig. 4 Steroidal glycosides isolated from the bulbs of $A$. ursinum

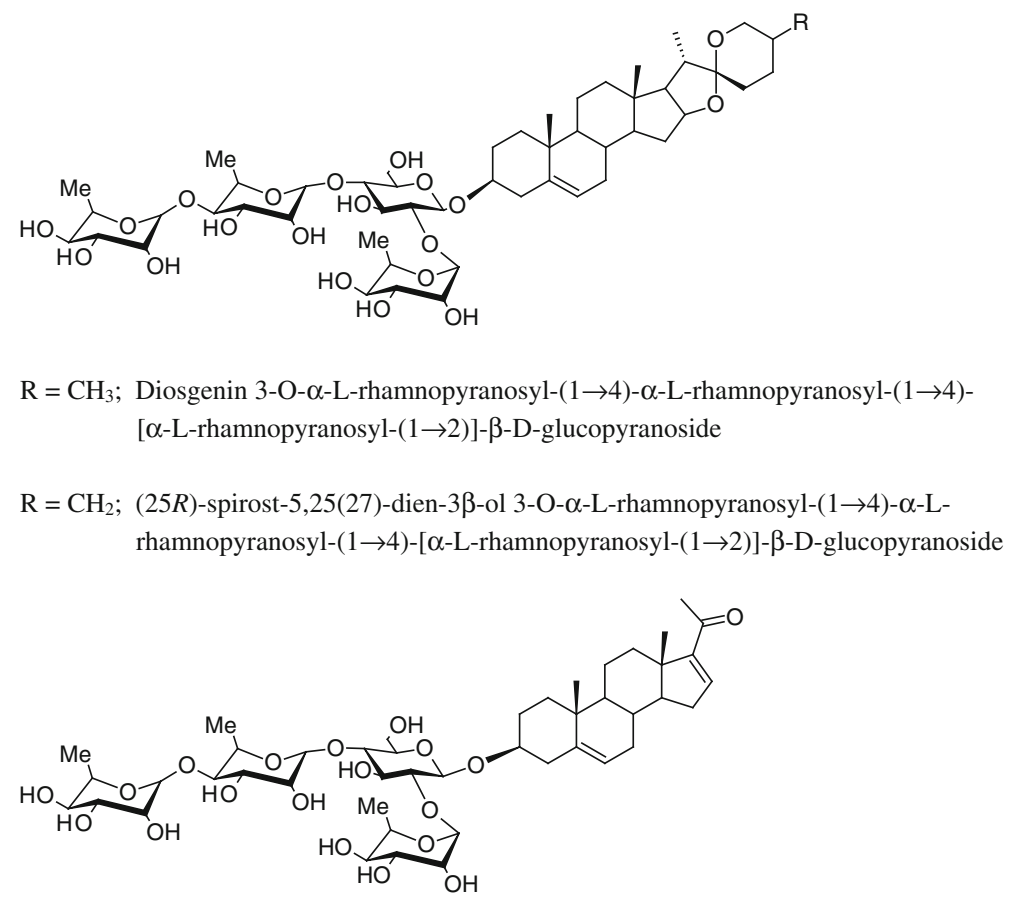

3-Hydroxy-pregna-5,16-dien-20-on 3-O- $\alpha$-L-rhamnopyranosyl-(1 $\rightarrow 4)-\alpha$-Lrhamnopyranosyl-( $(1 \rightarrow 4)$-[ $\alpha$-L-rhamnopyranosyl- $(1 \rightarrow 2)]-\beta$-D-glucopyranoside

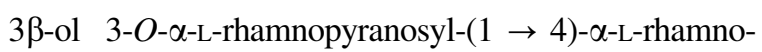
pyranosyl- $(1 \rightarrow 4)$-[ $\alpha$-L-rhamnopyranosyl- $(1 \rightarrow 2)]-\beta$ D-glucopyranoside (Fig. 4) (Sobolewska et al. 2006). A pregnane glycoside: 3-hydroxy-pregna-5,16-dien-20-on 3-O- $\alpha$-L-rhamnopyranosyl-( $1 \rightarrow 4)-\alpha$-L-rhamnopyranosyl-(1 $\rightarrow$ 4)-[ $\alpha$-L-rhamnopyranosyl- $(1 \rightarrow 2)]-\beta$-D-glucopyranoside has been identified as well (Fig. 4) (Sobolewska et al. 2006).

Diosgenin content in A. ursinum depended on the part of the plant and the time of harvest (Sobolewska et al. 2009). Methanol extract prepared from fresh bulbs collected in April, prior to flowering, yielded the highest content of diosgenin $(0,137 \%)$. In the extract made from leaves collected at the same time, the amount of diosgenin was 10 times lower, while in the one from leaves collected in March and June it was not detectable. Low diosgenin content in ramson does not make this plant species a valuable source for the isolation of this sapogenin.

In an ethanol extract from fresh leaves $\beta$-sitosterol 3-O- $\beta$-D-glucopyranoside was found (Sabha et al. 2012).

\section{Other}

Other interesting constituents identified in A. ursinum include lectins, which were isolated from bulbs, roots and leaves collected in April (Smeets et al. 1997). Root compounds were identical to those found in bulbs: AUAI, which is a heterodimeric lectin composed of polypeptides of 12.5 and $11.5 \mathrm{kDa}$, and AUAII a homodimeric lectin composed of polypeptides of $12 \mathrm{kDa}$. Both lectins are mannose-specific, and show a good reaction with synthetic $(1 \rightarrow 3)$ and $(1 \rightarrow 6)$ mannans. The ramson leaf lectin (AUAL) differs from the bulb lectins, and also from the leaf-specific lectins identified in other Allium species. It is a dimer composed of $12 \mathrm{kDa}$ subunits.

The bulbs are also rich in polysaccharides. According to Hegnauer, they may contain as much as $30-90 \%$ of mostly fructans (Hegnauer 1963). In the bulbs harvested between May and August the content of fructan U, consisting of fructose residues only, was estimated as 75-90 \% (Meier and Reid 1982). Unfortunately, no modern structure elucidation studies on this compound have been performed to date. The studies on reserve carbohydrates in A. ursinum from the Sheffield flora (United Kingdom) resulted in determination of the maximum fructan concentration in the bulbs harvested in summer, as $139 \mathrm{mg} / \mathrm{g}$ fresh weight (Hendry 1987).

A number of fatty acids were reported in the hexane extract from the bulbs. These were palmitic, linoleic, 


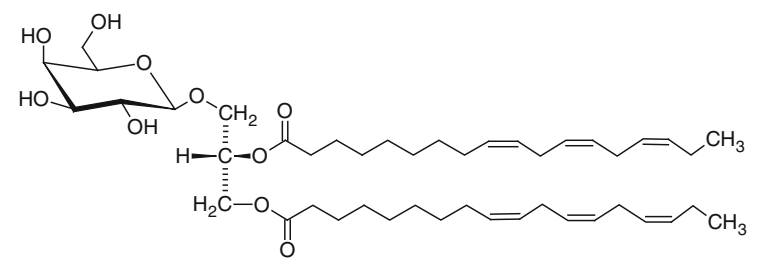

Fig. 5 2-Di- $O$ - $\alpha$-linolenoyl-3- $O$ - $\beta$-D-galactopyranosyl-sn-glycerol (DLGG) found in an ethanol extract from fresh leaves of $A$. ursinum

oleic, palmitoleic, stearic, $\alpha$-linolenic, and myristic acid (Wiater et al. 1998). Moreover, water extracts yielded fairly rare, but pharmacologically valuable $\gamma$ glutamylpeptides, and many amino acids, such as: asparagine, glutamine, aspartic acid, glutamic acid, arginine, alanine, glycine, threonine (Wagner and Sendl 1990). In an ethanol extract from fresh leaves 2-di- $O$ - $\alpha$-linolenoyl-3- $O$ - $\beta$-D-galactopyranosyl-snglycerol (DLGG) (Fig. 5), was identified (Sabha et al. 2012).

Ramson leaves seem to be relatively abundant in pigments, as compared to other Allium plants, the content of which amounts to: $2.87 \pm 0.03 \mathrm{mg} / \mathrm{g}$ of chlorophyll a, $1.35 \pm 0.01 \mathrm{mg} / \mathrm{g}$ of chlorophyll b, and as much as $9.99 \pm 0.01 \mathrm{mg} / \mathrm{g}$ of carotenoids (Štajner and Szöllosi Varga 2003). Comparative analysis of some macro- and microelements in $A$. ursinum and A. sativum showed that ramson contained higher levels of magnesium $(7,000 \mathrm{mg} / \mathrm{kg})$, manganese $(1,600 \mathrm{mg} / \mathrm{kg})$ and iron $(230 / \mathrm{mg} / \mathrm{kg})$ than garlic $(6,114,952,14 \mathrm{mg} / \mathrm{kg}$, respectively). $A$. ursinum is a rich source of adenosine $(120 \mathrm{mg} / \mathrm{kg})$ (Nagori et al. 2010).

Allium ursinum L. ssp. ucrainicum floral nectar volume and concentration were investigated in three different habitats in the Mecsek hills (South Transdanubia, Hungary) (Farkas et al. 2012). The study revealed that ramson produces low to medium volumes (ranged 0.1-3.8 $\mu \mathrm{l}$ ) of highly concentrated nectar (25-50\% sugar concentration). Freely sunexposed flowers produced lower quantity of nectar than covered flowers at a given time. The higher volume of nectar with higher sugar content was observed in populations living in optimal life conditions for A. ursinum (the sessile oak-hornbeam association). The plants living in the silver limeflowering ash rock forest, where the lack of sufficient nutrients was observed, produced lower quantities of nectar.

\section{Uses}

Ramson has been used for centuries to promote general health, and as the old English proverb says:

Eat leeks in Lide [March] and ramsons in May

And all the year after the physicians may play.

There is good evidence for the use of ramson by Mesolithic people. Charred bulbs of A. ursinum were identified-in the late Mesolithic settlement at Halsskov in Denmark (Kubiak-Martens 2002). It was hypothesized that ramson was one of the plants that contributed to the hunter-gatherer diet. A. ursinum was known to the early Celts and to the ancient Romans. The Greek physician Dioscorides mentioned four kinds of onion, among them A. ursinum and also attributed a detoxifying effect to the plant (Meyer et al. 1999; Richter 1999). Ramson was well known also in the Middle Ages; it belongs to the group of plants often found at medieval West Slavic archeological sites (Celka 2011). King Charles the Great, also known as Charlemagne, included A. ursinum in his Capitulare de Villis imperialibis, where he formally cataloged plants, mostly those possessing medicinal properties, and documented how the gardens should be planned and cared for (Clickner 2011). Hieronymus Bock provided drawings of the plant in his Kreutterbuch, Lonicerus judged wild garlic to be superior to regular garlic (Richter 1999; Błażewicz-Woźniak et al. 2011; Strzelecka and Kowalski 2000; Madaus 1938).

All parts of the plant are edible. For medical purposes leaves/herb-Allii ursini folium/herba, collected in April and May, and bulbs-Allii ursini bulbus, collected in September and October, are used. Ramson is usually collected from the wild. However, in Poland this species, which belongs to the group of 11 alliaceous plants growing wild there, has been partially protected since 2004 and is listed in the "Red list of plants and fungi in Poland", what made it impossible to be wild-harvested (Szafer et al. 1988; Zarzycki and Mirek 2006).

In European traditional medicine ramson has been generally recommended as digestive stimulant, antimicrobial agent, removing toxins from the body, and to prevent cardiovascular diseases (Treben 1992; Macků and Krejča 1989; Leporatti and Ivancheva 2003). It was often applied as a remedy in respiratory problems, such as common cold with fever or bronchitis. A. ursinum has been effective when used 
externally to support wound healing, in chronic skin disorders, and in acne.

In recent years there has been a growing interest in its use as a dietary supplement and food. There are some records that in the nineteenth century Switzerland butter made from milk of cows fed on ramson were used. Such milk tasted slightly of garlic. Apparently in Eberbach in Germany there is a festival called Bärlauchtage_-Bear's Garlic Days, which is devoted to this plant. Today, it is a common practice to use ramson in cuisine. Fresh leaves can be eaten raw or cooked, and as a kind of pesto. They are often added to soups, gnocchi, risotto, ravioli, and as a spice to flavor hard cheeses or spreads based on cottage cheeses. Leaves and flowers can be used as a garnish to salads, while ramson's bulbs can be used like common garlic.

Allium ursinum is also a component of dietary supplements available on the European market. For example, it is one of constituents found in the recipes used therapeutically in the University Hospital of Bucharest (Romania) (Epure et al. 2011). Such products as Api Ursomax and Memo Ursomax are recommended as detoxifying and antiatherogenic medicines. The former is additionally advertised as a mineralizing agent, while Memo Ursomax is claimed to be a memory stimulant.

\section{Pharmacological studies}

Modern pharmacological studies have confirmed many of the above mentioned traditional indications of ramson. For example, a great number of in vitro and in vivo experiments showed that $A$. ursinum is a plant with a high potential for the prevention and treatment of cardiovascular system diseases. Different extracts obtained from the fresh leaves of A. ursinum were tested in vitro on human platelet aggregation. The results showed a significant inhibitory activity of the ethanol extract on ADP-induced aggregation. The mechanism of action was similar to that of a reference drug Clopidogrel (Hiyasat et al. 2009). It was suggested, that the active compounds exerting antiaggregatory effect are 1,2-di- $O$ - $\alpha$-linolenoyl-3- $O$ - $\beta$-D-galactopyranosyl-sn-glycerol (DLGG) (Fig. 5) and $\beta$-sitosterol 3-O- $\beta$-D-glucopyranoside (Sabha et al. 2012). DLGG has previously been identified in a number of medicinal and food plants, and has been shown to possess antiinflmmatory activity (Larsen and Christensen 2007).

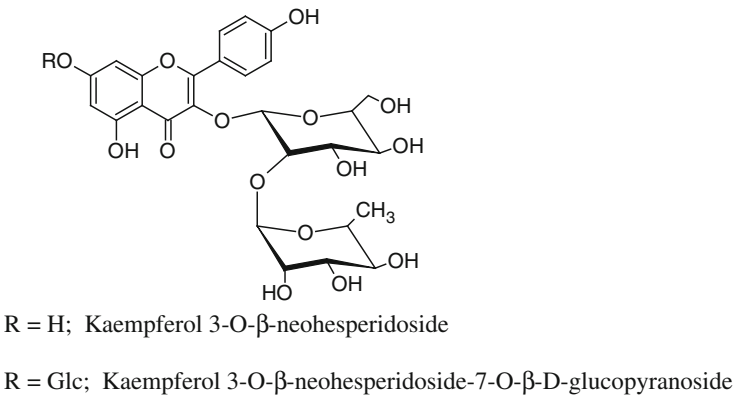

Fig. 6 Flavonoids exerting in vitro inhibitory activity on platelet aggregation induced by collagen

Moreover, two of the flavonoids present in ramson leaves: kaempferol 3-O- $\beta$-neohesperidoside-7-O- $\beta$-Dglucopyranoside and 3-O- $\beta$-neohesperidoside (Fig. 6), showed in vitro inhibitory activity on platelet aggregation induced by collagen (Carotenuto et al. 1996). As other kaempferol glycosides were inactive, it was concluded that the presence of $p$-coumaroyl group in the molecule and the increase in the number of monosaccharides in the sugar residue deplete the antiplatelet potential of these compounds.

Ramson's administration affects also the activity of ACE. In vitro tests on the water extract from the leaves (at the concentration of $0.3 \mathrm{mg} / \mathrm{ml}$ ), showed higher inhibition of this enzyme activity as compared to garlic leaves extract (58 vs. 30 \%) (Sendl et al. 1992a). This probably resulted from the differences in glutamyl peptides contents. The in vitro study on the effect of the ramson essential oil on the artificial liposome membrane model demonstrated that the fluidity of the membrane close to the surface was statistically nonsignificantly changed, while in deeper layers the fluidity increased (Godevac et al. 2008). The authors postulated that further studies should be continued to estimate the role of $A$. ursinum volatile oil in the regulation of membrane functions in hypertension.

In vivo experiments on rats fed for 8 weeks standard diet with $2 \%$ of pulverized A. ursinum leaves showed significantly lower plasma ACE activity in the ramson group as compared to control (Rietz et al. 1993). The studies performed on Spontaneously Hypertensive Rats (Okamoto strain) that were fed with diet containing $1 \% \mathrm{w} / \mathrm{w}$ ramson (Pfannenschmidt, Inc. of Hamburg) showed that after 45 days it reduced final mean systolic blood pressure when compared to control $(173 \pm 0.7$ vs. $189 \pm 1.2 \mathrm{~mm} \mathrm{Hg}$ respectively) (Preuss et al. 2001). Diet enrichment with 
ramson was more effective than with garlic at the same concentration (the final SBP-175 $\pm 1.2 \mathrm{~mm} \mathrm{Hg}$ ). A. ursinum decreased elevated circulating insulin concentration and total cholesterol level, however HDL tended to increase. Similarly, when both garlics were consumed at lower concentrations- $0.1 \%(\mathrm{w} / \mathrm{w})$ systolic blood pressure readings at 10, 18, and 26 days were significantly lower in rats consuming ramson compared to the animals consuming common garlic. Authors concluded that these effects may be associated with high concentration of glutamyl peptides, adenosine or phenolic compounds in ramson. They suggested that consuming $A$. ursinum may result in a greater therapeutic benefit when compared to $A$. sativum at a given concentration. Animal studies demonstrated that ramson-containing diet may reduce the size of the ischemic zone and ischemia and reperfusion-induced arrhythmias (Rietz et al. 1993).

Ramson showed in vitro inhibitory activity on cholesterol synthesis. Chloroform and chloroform/ acetone extracts from A. ursinum bulbs, at concentrations of $166 \mu \mathrm{g} / \mathrm{ml}$, inhibited cholesterol biosynthesis by 49.3 and $48.9 \%$, respectively. The results were nearly identical to those obtained for garlic extracts. Of the pure investigated components present in the extracts ajoene, methyl ajoene, 2-vinyl-4H-1,3-dithiin and allicin were the strongest cholesterol synthesis inhibitors, providing at the concentration of $10^{-3} \mathrm{M}$ the inhibition values of $69.5,72,58.4$, and $52.2 \%$, respectively (Sendl et al. 1992b). Pharmacological studies have also revealed that chloroform and acetone/chloroform extracts from ramson exerted in vitro inhibitory activity on 5-lipoxygenase and cyclooxygenase, however they were less effective than the corresponding garlic extracts (Sendl et al. 1992a). Thrombocyte aggregation test revealed no differences between A. ursinum and A. sativum extracts (Sendl et al. 1992a).

As was mentioned above, A. ursinum has been valued in traditional medicine as an antimicrobial agent used either internally or externally. There is a substantial number of reports in which the antimicrobial activity of various extracts prepared from different plant parts were tested in vitro against a wide array of bacterial and fungal strains.

Comparative analysis of water and methanol extracts from ramson herb (at the concentration range $0.16-83.7$ and $0.06-35.5 \mathrm{mg} / \mathrm{ml}$, respectively) showed that the latter was more active against microbes. It inhibited the growth of the following bacteria: Staphylococcus aureus, Bacillus subtilis, Escherichia coli, Proteus mirabilis, Salmonella enteritidis, and fungi: Cladosporium sp., Aspergillus niger, Rhizopus nigricans, Geotrichum candidum, Penicillium expansum, Candida lipolytica, Mycoderma, Saccharomycopsis fibuligera (Synowiec et al. 2010). The average antibacterial MIC value was $35 \mathrm{mg} / \mathrm{ml}$ with the exception of $S$. aureus ATTC 25923 strain, in the case of which the MIC was $17.7 \mathrm{mg} / \mathrm{ml}$. The highest antifungal effect was observed against $C$. lipolytica (MIC $=8.9 \mathrm{mg} / \mathrm{ml}$ ), whereas for other tested strains it was less pronounced $(\mathrm{MIC}=17.7 \mathrm{mg} / \mathrm{ml})$, however still much higher in comparison to the water extract (concs. $41.9-83.7 \mathrm{mg} / \mathrm{ml}$ ). The antibacterial activity of the water extract was seen only against B. subtilis ATTC 6633 (at $83.7 \mathrm{mg} / \mathrm{ml}$ ). A water extract (at $\mathrm{pH} \mathrm{7.0,} \mathrm{adjusted} \mathrm{with} 0.1 \mathrm{~mol} / \mathrm{l}$ $\mathrm{K}_{2} \mathrm{HPO}_{4}$ ) from $A$. ursinum leaves exhibited antibacterial activity in vitro against Listeria monocytogenes, $S$. aureus, E. coli, and Salmonella enterica subsp. enterica (Sapunjieva et al. 2012). The inhibition zones were greater in the case of Gram (+) bacteria.

A comparative analysis of the in vitro germination and growth inhibitory effects of the ethanol extracts from flowers and leaves of $A$. ursinum against $A$. niger, Botrytis cinerea, Botrytis paeoniae, Fusarium oxysporum f.sp. tulipae, Penicilium gladioli and Sclerotina sclerotiorum showed that the flower extract possessed the highest antifungal activity (MIC 100, $60,70,140,90$, and $60 \mu \mathrm{g} / \mathrm{ml}$, respectively). The authors claimed that the antifungal effects of the extracts could be positively correlated with allicin content: $1.946 \mathrm{mg}$ allicin/ml flower extract versus $0.028 \mathrm{mg}$ allicin $/ \mathrm{ml}$ leaf extract (Parvu et al. 2011). Pure allicin at concentrations $1.57-6.25 \mu \mathrm{g} / \mathrm{ml}$ showed inhibitory activity against Candida, Cryptococcus, Trichophyton, Epidermophyton, and Microsporum strains (Ankri and Mirelman 1999).

Antimicrobial activity of the bulb juice of $A$. ursinum was correlated with storage temperature and $\mathrm{pH}$ levels. Its activity against selected bacteria and fungi decreased on storage at the temperature above $4{ }^{\circ} \mathrm{C}$ and with an increase in the $\mathrm{pH}$ value (Tynecka et al. 1993).

The antimicrobial activity of different extracts (acetone, chloroform, ethyl acetate, $n$-butanol and water) from fresh flowers and leaves of Bulgarian ramson was studied. Acetone extracts from both parts 
and chloroform extract from the leaves were active against $S$. aureus (MIC $625 \mu \mathrm{g} / \mathrm{ml}$ ), while none of the extracts inhibited the growth of $E$. coli. The chloroform extract from the leaves showed inhibitory effect on Candida albicans (MIC $312 \mu \mathrm{g} / \mathrm{ml}$ ), as well (Ivanova et al. 2009). The fresh water extract from the bulbs inhibited the growth of different Candida strains, with MIC ranging from $1 \mathrm{mg} / \mathrm{ml}$ to $4 \mathrm{mg} / \mathrm{ml}$ depending on the particular yeast strain. The adhesion of Candida ssp. isolates to catheters (silicone-elastomer-coated latex urinary Foley catheter and PCV Thorax catheter) was not prevented by the extract even at the maximal concentration of $4.0 \mathrm{mg} / \mathrm{ml}$ (Chudzik et al. 2010). The extracts prepared from fresh $A$. ursinum leaves collected in Romania during blossoming phase inhibited the growth of Candida ssp. ( $C$. albicans, C. famata, C. glabrata, C. krusei) at concentrations ranging from 0.5 to $4.0 \mathrm{mg} / \mathrm{ml}$ (Bagiu et al. 2010).

The broad spectrum of antimicrobial activity of Allium plants is generally associated with sulfurcontaining compounds, however our own studies have shown that other constituents may as well contribute to that effect, to some extent. The inhibitory activity of a mixture of diosgenin tetrasaccharide and $(25 R)$-spirost-5,25(27)-dien-3 $\beta$-ol tetrasaccharide isolated from the bulbs against Candida glabrata and C. parapsilosis was determined, with MIC values of 200 and $250 \mu \mathrm{g} / \mathrm{ml}$, respectively (Sobolewska et al. 2003). Both compounds however, were ineffective against Pseudomonas aeruginosa and A. niger at concentrations up to $400 \mu \mathrm{g} / \mathrm{ml}$, by the disc diffusion method. With regard to antifungal properties against Trichophyton mentagrophytes and Microsporum canis the saponin mixture was active at the concentration $400 \mu \mathrm{g} / \mathrm{ml}$ (Sobolewska et al. 2006).

There were also some studies which evaluated the potential of ramson against parasites. For example, the juice from the bulbs was effective against free living nematode Rhabditis sp., larvae of Nippostrongylus brasiliensis, and hindered the development of Ascaris suum eggs (Chybowski 1997).

Isolated ramson's lectins were assessed for potential inhibitory effect against HIV-1- and HIV-2induced cytopathicity in MT4 cells (Smeets et al. 1997). The $\mathrm{EC}_{50}$ values (the concentration required to protect MT4 cells against cytopathicity of HIV by $50 \%$ ) of bulbs and leaf lectins were about 3 and $5 \mu \mathrm{g} / \mathrm{ml}$ for HIV-1 and HIV-2, respectively. The specific agglutination activity (the lowest concentration which still yields a visible agglutination of a $1 \%$ suspension of erythrocytes) of AUAL, AUAI and AUAII was the same (being $1.2 \mu \mathrm{g} / \mathrm{ml}$ ). A. ursinum lectins were more potent agglutinins than the $A$. sativum bulb lectins ASAI and ASAII (specific activities being 6 and $100 \mu \mathrm{g} / \mathrm{ml}$, respectively), but less active than the garlic leaf lectin $(0.2 \mu \mathrm{g} / \mathrm{ml})$.

The occurrence in various parts of the plant of constituents with well-known antioxidant properties, such as flavonoids or carotenoids, urged investigations that would confirm ramson's antioxidative potential. As was shown, extracts from different parts exhibited high free radicals scavenging activity. The antioxidant effect of ramson leaves may be associated not only with the presence of phenolic compounds but also with high activity of antioxidant enzymes, like catalase and peroxidase $(11.48 \pm 2.90 \mathrm{U} / \mathrm{mg}$ protein and $8.85 \pm$ $0.19 \mathrm{U} / \mathrm{mg}$ protein, respectively), whereas in the bulbs, with superoxide dismutase $(31.43 \pm 6.96 \mathrm{U} / \mathrm{mg}$ protein) (Štajner et al. 2008; Štajner and Szöllosi Varga 2003).

Also, the volatile oil of ramson has been tested, however it demonstrated poor antioxidant activity against $\mathrm{DPPH}^{+}$and $\mathrm{ABTS}^{+}$in comparison to $\mathrm{BHT}$ (butylated hydroxytoluene) and Trolox. On the other hand, in the beta-carotene-linoleic bleaching test the oil showed an effect comparable to that of BHT (Godevac et al. 2008). Based on these results, the authors concluded that the antioxidant effect depends on the method used, and also on which free radical generator or oxidant is involved (Godevac et al. 2008). It seems therefore mandatory to employ different analytical methods that would varying oxidation initiators and targets.

Nevertheless, some isolated ramson volatile oil constituents have revealed promising antioxidant properties. Diallyl disulfide increased the intracellular content of reduced glutathione in rat red blood cells, while diallyl sulfide enhanced the activity of antioxidative enzymes, and activated Nrf2 protein, what resulted in suppression of inflammatory cytokines (Wu et al. 2001; Kalayarasan et al. 2009).

Other pharmacological activities which were reported for A. ursinum include in vitro cytotoxicity. Nine different extracts (chloroform, methanol, and water) prepared by hot extraction of fresh leaves, flowers, and flower stems were analysed in vitro against murine cancer cell lines melanoma B16 and sarcoma 
XC (Trypan Blue Exclusion Test of Cell Viability) (Sobolewska et al. 2012). The methanol extracts from the aerial parts and the aqueous extracts from leaves and flowers were inactive or only slightly active over the entire concentration range (10-200 $\mu \mathrm{g} / \mathrm{ml})$ against both cell lines, while the aqueous extracts from flower stems showed no activity towards melanoma B16 cells. The chloroform extract from flower stems showed the most promising cytotoxic activity: at the concentration of $60 \mu \mathrm{g} / \mathrm{ml}$ of this extract $100 \%$ of melanoma B16 cells were killed after $24 \mathrm{~h}$, while at the concentration of $20 \mu \mathrm{g} / \mathrm{ml}$-after $48 \mathrm{~h}$. In both cell lines colchicine had an $\mathrm{ED}_{50}$ value lower than $2 \mu \mathrm{g} / \mathrm{ml}(0.5 \pm 0.003-$ melanoma B16; $1.5 \pm 0.005$-sarcoma XC) after $24 \mathrm{~h}$ (Sobolewska et al. 2012). Moreover, cytotoxic activity of a mixture of diosgenin tetrasaccharide and (25R)spirost-5,25(27)-dien-3 $\beta$-ol tetrasaccharide on melanoma B16, sarcoma XC and human fibroblasts HSF was evaluated as well. The saponin mixture was found active against murine melanoma B16 and sarcoma XC. It exhibited $100 \%$ effect at $2 \mu \mathrm{g} / \mathrm{ml}$ on both strains. It showed no activity towards human fibroblasts HSF at concentrations below $3 \mu \mathrm{g} / \mathrm{ml}$ (Sobolewska et al. 2006).

Diallyl disulfide (a component of ramson volatile oil) inhibited the proliferation of various human cancer cell lines, including breast, lung, colon cancers, lymphomas and neuroblastoma. The mechanism of action involved cell cycle arrest or apoptosis. Also, diallyl trisulfide induced apoptosis in human prostate cancer cell lines PC-3 and DU-145 (Lai et al. 2012).

\section{Adverse reactions}

Generally, A. ursinum is recognized as safe. However, there is some evidence of hemolytic anemia due to oxidative damage to erythrocytes following the consumption of other Alliums by domestic and farm animals (Munday et al. 2003). It seems that diallyl triand tetrasulfides, which are highly toxic to erythrocytes, may be largely responsible for this effect, and these compounds are present in ramson volatile oil, as well. Even though there were no reports of hemolysis associated with Allium plants consumption in humans, certain individuals whose erythrocytes are unusually vulnerable to oxidative damage, should consume garlic with caution. Case reports of allergic reactions to some garlic constituents have been also described (Borelli et al. 2007), and such compounds as diallyl disulfide, allylpropyl sulfide and allicin were identified as allergens. All are present in various A. ursinum preparations as well. The study on garlic-allergic patients in Taiwan revealed that garlic C,S-lyase (alliinase) was a major Allium sativum allergen (Kao et al. 2004). As this enzyme showed cross-reactivity with C,S-lyases from other species, the authors concluded that this molecule is a common allergen in Allium plants. The potential of A. ursinum to enhance existing anticoagulant therapy should be taken into consideration, as well.

Even though the garlic-like odor of ramson should enable its unambiguous identification, it should be noted that there were some cases of fatal poisoning by ingestion of toxic plants, the leaves of which, due to a similar shape, were mistakenly wildharvested as ramson. These were, in particular, autumn crocus (meadow saffron, Colchicum autumnale), the lily-of-the-valley (Convallaria majalis), and white hellebore (Veratrum album) (Colombo et al. 2010; Sundov et al. 2005; Gilotta and Brvar 2010; Klintschar et al. 1999).

\section{Conclusions}

Despite centuries of use of ramson as a substitute for garlic (A. sativum), pharmacological studies on $A$. ursinum bulbs and leaves have begun fairly recently, that is about 20 years ago. Thus, data referring to $A$. sativum, which is a species much valued for its therapeutic potential are much more abundant, even though the conclusions related to its clinical efficacy are often inconsistent. A broad spectrum of biological activities recorded for ramson extracts and the presence of chemical compounds with high therapeutic potential, makes this plant species a possible candidate for future development as a medicinal product. Undoubtedly, some problems that may appear are associated with producing a uniform plant material as ramson composition is very sensitive to changes in growth conditions what could hinder large scale production and standardization. Nevertheless, it is worth noting, that definitely in recent years as been recognized as a valuable spice plant.

Open Access This article is distributed under the terms of the Creative Commons Attribution License which permits any use, distribution, and reproduction in any medium, provided the original author(s) and the source are credited. 


\section{References}

Andersson ME (1993) Aluminium toxicity as a factor limiting the distribution of Allium ursinum L. Ann Bot 72:607-611

Ankri S, Mirelman D (1999) Antimicrobial properties of allicin from garlic. Microbes Infect 1(2):125-129

Bagiu RV, Vlaicu B, Butnariu M (2010) Chemical composition and in vitro antifungal activity screening of the Allium ursinum L. (Liliaceae). Int J Mol Sci 13:426-1436

Benkeblia N, Lanzotti V (2007) Allium thiosulfinates: chemistry, biological properties and their potential utilization in food preservation. Food 1(2):193-201

Berger F (1960) Handbuch der Drogenkunde. Wilhelm Maudrich/Verlag, Vienna

Bierzychudek P (1982) Life histories and demography of shadetolerant temperate forest herbs: a review. New Phytol 90:757-776

Błażewicz-Woźniak M, Michowska A (2011) The growth, flowering and chemical composition of leaves of three ecotypes of Allium ursinum L. Acta Agrobot 64(4):171-180

Błażewicz-Woźniak M, Kęsik T, Michowska AE (2011) Flowering of bear garlic (Allium ursinum L.) cultivated in the field at varied nitrogen nutrition and mulching. Acta Sci Pol Hortorum Cultus 10(3):133-144

Block E, Naganathan S, Putman D et al (1992) Allium chemistry: HPLC analysis of thiosulfinates from onion, garlic, wild garlic (ramsoms), leek, scallion, shallot, elephant (great-headed) garlic, chive, and chinense chive. Uniquely high allyl to methyl ratios in some garlic samples. J Agric Food Chem 40:2418-2430

Böhling N (2008) Eine Hypothese zur Ableitung des Namens „Bär“lauch. Ber Inst Landschafts-Pflanzenökologie Univ Hohenheim Heft 17:199-204

Borelli F, Capasso R, Izzo AA (2007) Garlic (Allium sativum L.): adverse effects and drug interactions in humans. Mol Nutr Food Res 51:1386-1397

Boscher J, Auger J, Mandon N et al (1995) Qualitative and quantitative comparison of volatile sulphides and flavour precursors in different organs of some wild and cultivated garlics. Biochem Syst Ecol 23(7/8):787-791

Carotenuto A, De Feo V, Fattorusso E et al (1996) The flavonoids of Allium ursinum. Phytochemistry 41(2):531-536

Celka Z (2011) Relics of cultivation in the vascular flora of medieval West Slavic settlements and castles. Biodivers Res Conserv 22:1-110

Chase MW, Reveal JL, Fay MF (2009) A subfamilial classification for the expanded asparagalean families Amaryllidaceae, Asparagaceae and Xanthorrhoeaceae. Bot J Linn Soc 161(2):132-136

Chudzik B, Malm A, Rajtar B et al (2010) The fresh extracts of Allium species as potential in vitro agents against planktonic and adherent cells of Candida spp. Ann Univ Mariae Curie-Sklodowska, DDD Pharm 23(1):73-78

Chybowski J (1997) Badania aktywności przeciwrobaczej wyciągów czosnkowych. Herba Pol 43(4):383-387

Činčura F, Feráková V, Májovský J et al (1990) Pospolite rośliny środkowej Europy. PWRiL, Warszawa

Clickner T (2011) A miscellany of garlic: from paying off pyramids and scaring away tigers to inspiring courage and curing hiccups, the unusual power behind the world's most humble vegetable. F+W Media, Cincinnati

Colombo ML, Assisi F, Puppa TD et al (2010) Exposures and intoxications after herb-induced poisoning: a retrospective hospital-based study. J Pharm Sci Res 2(2):123-136

Condrat D, Mosoarca C, Zamfir AD et al (2010) Qualitative and quantitative analysis of gallic acid in Alchemilla vulgaris, Allium ursinum, Acorus calamus and Solidago virga-aurea by chip-electrospray ionization mass spectrometry and high performance liquid chromatography. Cent Eur J Chem 8(3):530-535

Copra-Janicijevic A, Muradic S, Huseinovic S et al (2008) Isolation of essential oils of Allium ursinum L. from Bosnia. Planta Med 74:PI42

Defelice MS (2003) Wild garlic, Allium vineale L.- -little to crow about. Weed Technol 17(4):890-895

Djurdjevic L, Dinic A, Pavlovic P et al (2004) Allelopathic potential of Allium ursinum L. Biochem Syst Ecol 32:533-544

Eggert A (1992) Dry matter economy and reproduction of a temperate forest spring geophyte Allium ursinum. Ecography 15:45-52

Ellenberg HH (1988) Vegetation ecology of Central Europe. Cambridge University Press, Cambridge, New York

Epure LI, Roman GV, Mărăcineanu R (2011) Studies on medicinal and aromatic plants used in the therapeutic recepies in the Bucharest university hospital. Science Papers UASVM, LIV, pp 304-313

Ernst WHO (1979) Population biology of Allium ursinum in northern Germany. J Ecol 67:347-362

Farkas A, Molnàr R, Morschhauser T et al (2012) Variation in nectar volume and sugar concentration of Allium ursinum L. ssp. ucrainicum in three habitats. ScientificWorldJournal 2012:138579

Friesen N, Fritsch RM, Blattner FR (2006) Phylogeny and new intrageneric classification of Allium (Alliaceae) based on nuclear ribosomal DNA its sequences. Aliso 22:372-395

Fritsch RM, Keusgen M (2006) Occurrence and taxonomic significance of cysteine sulphoxides in the genus Allium L. (Alliaceae). Phytochemistry 67:1127-1135

Gilotta I, Brvar M (2010) Accidental poisoning with Veratrum album mistaken for wild garlic (Allium ursinum). Clin Toxicol (Phila) 48(9):949-952

Gîtin L, Dinică R, Parnavel R (2012) The influence of extraction method on the apparent content of bioactive compounds in Romanian Allium spp. leaves. Not Bot Horti Agrobot Cluj Napoca 40(1):93-97

Godevac D, Vujisić L, Mojović M et al (2008) Evaluation of antioxidant capacity of Allium ursinum L. volatile oil and its effect on membrane fluidity. Food Chem 107(4):1692-1700

Govaerts R (ed) (2011) World checklist of selected plant families. Royal Botanic Gardens, Richmond, Surrey

Hanelt P, Büttner R (2001) Mansfeld's encyclopedia of agricultural and horticultural crops. Springer, Berlin, New York

Hegnauer R (1963) Chemotaxonomie der Pflanzen. Birkhäuser/ Verlag, Basel

Hendry G (1987) The ecological significance of fructan in a contemporary flora. New Phytol 106(Suppl.):201-216

Hermy M, Honnay O, Firbank L et al (1999) An ecological comparison between ancient and other forest plant species 
of Europe, and the implications for forest conservation. Biol Conserv 91(1):9-22

Hiyasat B, Sabha D, Grötzinger K et al (2009) Antiplatelet activity of Allium ursinum and Allium sativum. Pharmacology 83(4):197-204

Ivanova A, Mikhova B, Najdenski H et al (2009) Chemical composition and antimicrobial activity of wild garlic Allium ursinum of Bulgarian origin. Nat Prod Commun 4(8):1059-1062

Jandl R, Kopeszki H, Glatzel G (1997) Effect of dense Allium ursinum (L.) ground cover on nutrient dynamics and mesofauna of a Fagus sylvatica (L.) woodland. Plant Soil 189:245-255

Kalayarasan S, Prabhu PN, Sriram N et al (2009) Diallyl sulfide enhances antioxidants and inhibits inflammation through the activation of Nrf2 against gentamicin-induced nephrotoxicity in Wistar rats. Eur J Pharmacol 606(1-3):162-171

Kao S-H, Hsu C-H, Su S-N et al (2004) Identification and immunologic characterization of an allergen, alliin lyase, from garlic (Allium sativum). J Allergy Clin Immunol 113(1):161-168

Karpaviciene B (2006) Distribution of Allium ursinum L. in Lithuania. Acta Biol Univ Daugavp 6(1-2):117-122

Keusgen M, Jünger M, Krest I et al (2003) Development of biosensor specific for cysteine sulfoxides. Biosens Bioelectron 18(5-6):805-812

Klintschar M, Beham-Schmidt C, Radner H et al (1999) Colchicine poisoning by accidental ingestion of meadow saffron (Colchicum autumnale): pathological and medicolegal aspects. Forensic Sci Int 106(3):191-200

Kovacs JA (2007) Data to vegetation biology and coenological relations of Allium ursinum L. stands in Eastern Transylvania. Kanitzia 15:63-76

Kubec R, Svobodova M, Velisek J (2000) Distribution of S-alk(en)ylcysteine sulfoxides in some Allium species. Identification of a new flavour precursor: S-ethylcysteine sulfoxide (ethiin). J Agric Food Chem 48:428-433

Kubiak-Martens L (2002) New evidence for the use of root foods in pre-agrarian subsistence recovered from the late Mesolithic site at Halsskov, Denmark. Veg Hist Archaeobot 11:23-31

Lai KC, Kuo CL, Ho HC et al (2012) Diallyl sulfide, diallyl disulfide and diallyl trisulfide affect drug resistant gene expression in colo 205 human colon cancer cells in vitro and in vivo. Phytomedicine 19:625-630

Landshuter J, Lohmüller EM, Knobloch K (1994) Purification and characterization of C-S-lyase from ramson, the wild garlic, Allium ursinum. Planta Med 60:343-347

Larsen E, Christensen LP (2007) Common vegetables and fruits as a source of 1,2-di-O- $\alpha$-linolenoyl-3-O- $\beta$-D-galactopyranosyl-sn-glycerol. A potential anti-inflammatory and antitumor agent. J Food Lipids 14:272-279

Leporatti ML, Ivancheva S (2003) Preliminary comparative analysis of medicinal plants used in the traditional medicine of Bulgaria and Italy. J Ethnopharmacol 87:123-142

Leuschner C, Lendzion J (2009) Air humidity, soil moisture and soil chemistry as determinants of the herb layer composition in European beech forests. J Veg Sci 20:288-298

Lyantagaye SL (2011) Ethnopharmacological and phytochemical review of Allium species (sweet garlic) and Tulbaghia species (wild garlic) from Southern Africa. Tanzan J Sci 37:58-72

Macků J, Krejča J (1989) Atlas roślin leczniczych. Zakład Narodowy im. Ossolińskich, Wrocław

Madaus G (1938) Lehrbuch der Biologischen Heilmittel, vol 1. Georg Thieme/Verlag, Leipzig, pp 480-483

Maine Department of Agriculture, Conservation and Forestry (2013) Maine rare plant list and rare plant fact sheets. Allium canadense. http://Maine.gov. Cited 10 Feb 2013

Meier H, Reid JSG (1982) Reserve polysaccharides other than starch in higher plants. In: Loewus FA, Tanner W (eds) Plant carbohydrates I. Encyclopedia of plant physiology, vol 13/A. Springer, Berlin

Meyer FG, Emmart Trueblood E, Heller JL (1999) The great herbal of Leonhart Fuchs. De historia stripium commentari insignes, 1542. Stanford University Press, Stanford

Morschhauser T, Rudolf K, Botta-Dukát Z et al (2009) Densitydependence in the establishment of juvenile Allium ursinum individuals in a monodominant stand of conspecific adults. Acta Oecol 35(5):621-629

Munday R, Munday JS, Munday CM (2003) Comparative effects of mono-, di-, tri-, and tetrasulfides derived from plants of the Allium family: redox cycling in vitro and hemolytic activity and phase 2 enzyme induction in vivo. Free Radic Biol Med 34(9):1200-1211

Nagori BP, Solanki R, Sharma N (2010) Natural healing agent: garlic, an approach to healthy life. IJRAP 1(2): 358-366

Oborny B, Botta-Dukat Z, Rudolf K, Morschhauser T (2011) Population ecology of Allium ursinum, a space-monopolizing clonal plant. Acta Bot Hung 53(3-4):371-388

Oszmiański J, Kolniak-Ostek J, Wojdyło A (2013) Characterization and content of flavonol derivatives of Allium ursinum L. plant. J Agric Food Chem 61:176-184

Parvu M, Parvu AE, Vlase L et al (2011) Antifungal properties of Allium ursinum L. ethanol extract. J Med Plants Res 5(10):2041-2046

Preuss HG, Clouatre D, Mohamadi A et al (2001) Wild garlic has a greater effect than regular garlic on blood pressure and blood chemistries of rats. Int Urol Nephrol 32(4): 525-530

Puxbaum H, König G (1997) Observation of dipropenyl disulfide and other organic sulfur compounds in the atmosphere of a beech forest with Allium ursinum ground cover. Atmos Environ 31(2):291-294

Rejewski M (1996) Pochodzenie łacińskich nazw roślin polskich. Przewodnik botaniczny. Książka i Wiedza, Warszawa

Richter T (1999) Bärlauch in Medizin und Mythologie. Pharm Ztg 144:2197-2198

Rietz B, Isensee H, Strobach H et al (1993) Cardioprotective actions of wild garlic (Allium ursinum) in ischemia and reperfusion. Mol Cell Biochem 119:143-150

Rola K (2012) Taxonomy and distribution of Allium ursinum (Liliaceae) in Poland and adjacent countries. Biologia 67(6):1080-1087

Rychnovská M, Bednář V (1998) Floodplain forest: herb layer as indicator of its ecological status. Acta Univ Palacki Olomuc Fac Rer Nat Biol 36:7-15

Sabha D, Hiyasat B, Grötzinger K et al (2012) Allium ursinum L.: bioassay-guided isolation and identification of a 
galactolipid and a phytosterol exerting antiaggregatory effects. Pharmacology 89(5-6):260-269

Sapunjieva T, Alexieva I, Mihaylova D et al (2012) Antimicrobial and antioxidant activity of extracts of Allium ursinum L. J Biol Sci Biotech SE/ONLINE:143-145

Schmitt B, Glodek J, Keusgen M (2002) Ontogenic changes of cysteine sulphoxides in Allium ursinum L. Revista de Fitoterapia 2(Suppl. 1) 224, B020

Schmitt B, Schulz H, Strosberg J et al (2005) Chemical characterization of Allium ursinum L. depending on harvesting time. J Agric Food Chem 53:7288-7294

Sendl A (1995) Allium sativum and Allium ursinum: part 1. Chemistry, analysis, history, botany. Phytomedicine 1(4):323-329

Sendl A, Wagner H (1991) Isolation and identification of homologues of ajoene and alliin from bulb-extracts of Allium ursinum. Planta Med 57(4):361-362

Sendl A, Elbl G, Steinke B et al (1992a) Comparative pharmacological investigations of Allium ursinum and Allium sativum. Planta Med 58(1):1-7

Sendl A, Schliack M, Löser R et al (1992b) Inhibition of cholesterol synthesis in vitro by extracts and isolated compounds prepared from garlic and wild garlic. Atherosclerosis 94(1):79-85

Shmanova IW, Krichfalushii WW (1995) Biomorphological and ecologo-coenotic characteristics of Allium ursinum L. in Carpathians. Rast Res 31(3):1-18

Smeets K, Van Damme EJ, Van Leuven F et al (1997) Isolation, characterization and molecular cloning of a leaf-specific lectin from ramsons (Allium ursinum L.). Plant Mol Biol 35(4):531-535

Sobolewska D, Janeczko Z, Galanty A, Trojanowska D (2003) Cytotoxic, antifungal and antibacterial activity of spirostanol saponin from ramson Allium ursinum L. In: Proceedings of the 3rd international symposium on natural drugs. Naples. 2-4 Oct 2003

Sobolewska D, Janeczko Z, Kisiel W et al (2006) Steroidal glycosides from the underground parts of Allium ursinum L. and their cytostatic and antimicrobial activity. Acta Pol Pharm Drug Res 63(3):219-223

Sobolewska D, Janeczko Z, Podolak I et al (2009) Densitometric analysis of diosgenin in methanolic extracts of Allium ursinum collected in different periods of plant development. J Planar Chromatogr 22(4):305-307

Sobolewska D, Galanty A, Michalik M (2012) Preliminary evaluation of cytotoxic activity of Allium ursinum extracts. Czas Aptek 12(228):41-44

Štajner D, Szöllosi Varga I (2003) An evaluation of the antioxidant abilities of Allium species. Acta Biol Szeged 47(1-4):103-106
Štajner D, Popović BM, Candanović-Brunet J et al (2008) Antioxidant and scavenger activities of Allium ursinum. Fitoterapia 79(4):303-305

Strzelecka H, Kowalski J (eds) (2000) Encyklopedia Zielarstwa i Ziołolecznictwa. PWN, Warszawa

Sundov Z, Nincevic Z, Definis-Gojanovic M et al (2005) Fatal colchicine poisoning by accidental ingestion of meadow saffron-case report. Forensic Sci Int 149(2-3):253-256

Synowiec A, Gniewosz M, Zieja I et al (2010) Porównanie właściwości przeciwdrobnoustrojowych ekstraktów Z czosnku niedźwiedziego (Allium ursinum). Zesz Probl Postępów Nauk Rol 553:203-209

Szafer W, Zarzycki W (1972) Szata roślinna Polski. PWN, Warszawa

Szafer W, Kulczyński S, Pawłowski B (1988) Rośliny polskie. PWN, Warszawa

Treben M (1992) Apteka Pana Boga. Porady i praktyka stosowania ziół leczniczych. Natur-Produkt TOM-MARK, Warszawa

Tynecka Z, Szcześniak Z, Głowniak K (1993) The effect of various environmental conditions on the antimicrobial activity of Allium ursinum. Planta Med 59(7 SUPPL):A701

Wagner H, Sendl A (1990) Barlauch und Knoblauch. Vergleichende chemische und pharmakologische Untersuchungen von Barlauch- und Knoblauchextrakten. Dtsch Apoth Ztg 33:1809-1815

Wiater M, Sobolewska D, Janeczko Z (1998) Fatty acids in lipid fraction from the undeground parts of Allium ursinum L. In: XVII Naukowy Zjazd Polskiego Towarzystwa Farmaceutycznego "Farmacja w perspektywie XXI w.". Streszczenia. Kraków. 10-13 Sept 1998

Wu CC, Sheen LY, Chen HW et al (2001) Effects of organosulfur compounds from garlic oil on the antioxidation system in rat liver and red blood cells. Food Chem Toxicol 39(6):563-569

Wu H, Dushenkov S, Ho CT et al (2009) Novel acetylated flavonoid glycosides from the leaves of Allium ursinum. Food Chem 115(2):592-595

Yoo KS, Pike LM (1998) Determination of flavor precursor compound S-alk(en)yl-L-cysteine sulfoxides by an HPLC method and their distribution in Allium species. Sci Hortic 75(1-2):1-10

Zarzycki K, Mirek Z (2006) Red list of plants and fungi in Poland. Czerwona lista roślin i grzybów Polski. Instytut Botaniki im. W. Szafera PAN, Kraków 